retroactively. All existing university staff would therefore retain the right to lifetime employment. Unsurprisingly, therefore, most senior university staff support the councils' recommendations, while many young researchers who have been waiting in line for permanent positions - often for years - are opposed to them.

To ease the situation of young researchers, the coalition government has, at Arima's urging, agreed to increase the number of postdoctoral fellows in Japan from the present level of 4,000 to 10,000 by the year 2000. That will help the many socalled 'over-doctors' (a Japanese term derived from English) who have PhDs but no permanent post and who continue doing research by supporting themselves with parttime jobs.

To pay for this, both Monbusho and the Science and Technology Agency have applied for extra funds next fiscal year (which begins on 1 April), and Monbusho plans to boost the salary for fellowships from $¥ 280,000(\$ 2,800)$ to $¥ 400,000$ a month to make them more attractive.

At the same time, Arima is urging the Japanese government to stop employing young scientists as research assistants, a position that provides lifetime employment. Instead, he would like it to appoint technicians to such posts, thereby helping to ease the chronic shortage of technical staff in universities. He hopes this policy will be adopted next year, "provided that they [young researchers] don't kill me first".

David Swinbanks

\title{
Europe to strengthen links on marine and polar projects
}

Paris. Scientists from 30 institutes in 17 European countries have agreed to set up two new bodies aimed at improving the coordination of marine and polar research in Europe. The European boards for marine and polar science, as they are known, will be established under the auspices of the European Science Foundation (ESF), based in Strasbourg, France. Each will have 20 members, overseen by a joint executive committee, and will be administered from the ESF.

The marine science board will be chaired by Daniel Cadet, deputy director of the Institut des Sciences de l'Univers of the Centre National de la Recherche Scientifique (CNRS). Barry Heywood, director of the British Antarctic Survey, will chair both the polar sciences board and the executive committee overseeing the two boards.

According to Heywood, the reason for setting up the boards, agreed at a meeting in Paris last week, is the need "to find quick answers to very important scientific problems at a time when budget resources are shrinking and research equipment is getting more expensive".

To achieve this, the meeting concluded that Europe needs large programmes lasting at least ten years, and costing more than ECU50 million (US\$61 million). Until now,

\section{Paris pendulum swings back into action}

\begin{abstract}
Paris. France's annual science festival - Science en Fête got off to a swinging start last week when the original Foucault pendulum (right) oscillated under the majestic dome of the national mausoleum, the Panthéon, for the first time since Léon Foucault used it to demonstrate Galileo's theory that the Earth turns on its axis.

Foucault's original pendulum bob - a brass-plated lead ball, $38 \mathrm{~cm}$ in diameter, weighing 28 kg - was taken from its home
\end{abstract} in the Conservatoire National des Arts et Métiers for the reconstruction. It was attached to the apex of the Panthéon dome, 67 metres above the ground, by a steel cable, and after its release by François Bayrou, France's Minister of Education, soared back and forth across the Panthéon, taking 16.5 seconds to complete each swing.

The science festival, which this year includes more than 1,800 scientific events, is unlikely to create

\section{IMAGE \\ UNAVAILABLE FOR COPYRIGHT REASONS}

\begin{abstract}
the same stir as Foucault's first demonstration of his pendulum, which proved an immediate success with the public and was subsequently reproduced in many other cities. Recognition of Foucault - an autodidact who also invented the gyroscope - by the scientific community took longer; he was admitted to the French Academy of Sciences only in 1865 , three years before his death.
\end{abstract}

most marine and polar programmes in Europe have tended to be national programmes lasting between one and three years, and the large programmes identified could not be afforded by one nation alone.

The first programme for which the boards will seek support is on climate change, the European Project for Ice Coring in the Antarctica (EPICA). Estimated to cost ECU50-ECU60 million, this will investigate whether the findings of ESF's Greenland Icecore Project (GRIP) - that the Earth's climate has been stable for around 10,000 years, but fluctuated violently before that - are a regional or global phenomena.

Other so-called 'grand challenges' identified at the meeting include a programme forecasting physical, chemical and biological processes in oceans and coastal seas over timescales ranging from seasons to decades, a project to map the Arctic Ocean and a study of the deep sea floor.

Half the funding for such programmes would come from European Union (EU) research funds, in particular, the Marine Science and Technology (MAST) programme - which has a budget of ECU228 million for the period 1994-98 - and environment programmes. The other half would come from national research agencies.

Proposals for EU funding would be required to compete with other bids under standard research grant procedures. Nevertheless, the European Commission, which has been involved in the creation of the boards from the outset, is enthusiastic about the prospect of large cooperative programmes. "The scientists took this initiative, and we are keen to support them," says one commission official.

Heywood says the boards are willing to tailor proposals to the commission's requirements, pointing out that many of the boards' members are also members of the programme committees. But he emphasizes that the boards will proceed modestly. "We want to be pragmatic", he says, with each national group first identifying its own interests and then discussing possible collaboration with others. The boards' role will be primarily to implement agreed projects, he says, not to act as a talking shop. "We need to obtain street credibility, in particular with national governments.'

One aim of the boards will be to seek better use of Europe's existing research fleet of 20 large vessels, as well as costly facilities such as submersibles and satellites. Ultimately their goal is to provide Europe with a single voice for marine and polar science in negotiations with the European Commission and other international bodies.

Declan Butler 